\title{
Skin diseases reported by workers from UNESP campus at Rubião Jr, Botucatu-SP (Brazil)*
}

\author{
Patrícia Sayuri Ishiy ${ }^{1}$ \\ Ana Carolina Handel ${ }^{1}$
}

\author{
Leandro Ramos e Silva ${ }^{1}$ \\ Hélio Amante Miot ${ }^{1}$
}

Mariana Álvares Penha ${ }^{1}$

DOI: http://dx.doi.org/10.1590/abd1806-4841.20142875

Abstract: There are few populational studies to estimate the dimension of dermatological diseases. We performed a survey with 515 employees from UNESP campus, Botucatu (SP), exploring demographic data, medical appointments and dermatological diagnoses. Additionally, we induced questions about prevalent diseases. Appointments to the dermatologist were reported by $77 \%$ of subjects. The main dermatoses spontaneously reported were mycoses, allergies, nevi and viral warts. There were association of juvenile acne and males (OR=2.3), melasma and females $(\mathrm{OR}=8.0)$, and onychomycosis with older age $(\mathrm{OR}=1.05)$. Surveys are important to know the demand for dermatology care, besides directing formulation of public health policy and medical education.

Keywords: Acne vulgaris; Alopecia; Epidemiology; Melanosis; Nail diseases; Onychomycosis; Prevalence; Skin diseases

There are few population or primary care studies that assess the frequency of dermatoses. This implies that the prevalence of cutaneous diseases should be evaluated with the followed-up cases at specialized health care services. ${ }^{1}$

Population-based surveys are important to allow more reliable epidemiological indicators, besides detecting the demand for dermatological assistance, so as to direct the establishment of public health policies and medical education.

A research of this kind was done in France in 2002 , through which a mail survey of 18,137 French citizens, of all ages, estimated that $86.8 \%$ of the population reported some dermatological disease from birth. The most reported diseases were acne, viral warts, contact dermatitis, mycoses and labial herpes. ${ }^{2}$

Our study goal was to evaluate the prevalence of dermatoses reported by the population of adult workers in a public institution of a Brazilian city.

A population-based survey was conducted at the University Campus of Unespa at Rubião Jr, Botucatu (SP), between April of 2012 and May of 2013, directed to adults ( $>18$ year-old) who performed professional activities there.

The following were studied: demographic and constitutional aspects, previous occurrence of skin diseases, dermatological appointments history, and, in induced form: personal antecedents of hair, acne and facial melasma problems (objective exam during interview).

Convenience sampling was performed, after campus mapping and planning of visits at different times. Sampling size was calculated for the estimate $( \pm 3 \%$ standard error) of prevalence of the most common dermatoses for a finite universe of 2000 employees. ${ }^{3}$ The sampling was supplemented with 5\% retired people, resulting in 505 subjects.

Categorical data were represented by percent proportions, confidence interval of 95\% (CI 95\%) and compared through multiple logistic regression. The measure of association used was Odds Ratio (OR). Continuous variables with normal distribution were represented by averages and standard deviations. A significance level of $5 \%$ was adopted.

The project was approved by the institution's Research and Ethics Committee (062/2012).

A total of 515 workers were interviewed. The main demographical data related to the dermatoses are on tables 1 and 2 . The high frequency of visits to dermatologist stands out (77\%).

Through multivariate analysis, women consulted the specialist more often than men $(82.5 \%$ x $69.7 \%$; $\mathrm{OR}=2.1 ; \mathrm{p}<0.01$ ); likewise, older employees presented higher chances of having had appointments $(\mathrm{OR}=1.02$;

\footnotetext{
Received on 16.06.2013.

Approved by the Advisory Board and accepted for publication on 01.07.2013.

Work performed at Department of Dermatology and Radiotherapy of Faculdade de Medicina de Botucatu da Universidade Estadual Paulista "Júlio de Mesquita Filho" (UNESP)- Botucatu (SP), Brazil.

Conflict of interest: None.

Financial Support: Project funded by FAPESP (no. 2012/07017-3)

Universidade Estadual Paulista "Júlio de Mesquita Filho" (UNESP)- Botucatu (SP), Brazil.
} 
TABLE 1: Main constitutional and demographic data of interviewed employees $(n=515)$

\begin{tabular}{|c|c|c|c|c|c|}
\hline \multirow{2}{*}{$\frac{\text { Variables }}{\text { Gender - N ( } \%)}$} & \multirow[t]{2}{*}{ Value } & \multicolumn{4}{|c|}{ CI 95\% } \\
\hline & & & & & \\
\hline Female & 297 & $(57.7 \%)$ & $50.5 \%$ & to & $64.9 \%$ \\
\hline Male & 218 & $(42.3 \%)$ & $35.1 \%$ & to & $49.5 \%$ \\
\hline Avg. Age (standard deviation) in years & 42.1 & $(11.2)$ & 40.5 & to & 43.7 \\
\hline \multicolumn{6}{|l|}{ Phototype - N (\%) } \\
\hline I-II & 148 & $28.7 \%$ & $22.1 \%$ & to & $35.3 \%$ \\
\hline III-IV & 214 & $41.6 \%$ & $34.4 \%$ & to & $48.7 \%$ \\
\hline V-VI & 153 & $29.7 \%$ & $23.0 \%$ & to & $36.4 \%$ \\
\hline \multicolumn{6}{|l|}{ Ascent - N (\%) } \\
\hline European & 444 & $(86.2 \%)$ & $81.2 \%$ & to & $91.2 \%$ \\
\hline African & 136 & $(26.4 \%)$ & $20.0 \%$ & to & $32.8 \%$ \\
\hline Asian & 15 & $(2.9 \%)$ & $0.5 \%$ & to & $5.4 \%$ \\
\hline Indigenous & 129 & $(25.0 \%)$ & $18.7 \%$ & to & $31.4 \%$ \\
\hline Other & 2 & $(0.4 \%)$ & $0.1 \%$ & to & $1.3 \%$ \\
\hline \multicolumn{6}{|l|}{ Racial autodenomination - N (\%) } \\
\hline White & 387 & $(75.1 \%)$ & $68.8 \%$ & to & $81.5 \%$ \\
\hline Mixed & 77 & $(15.0 \%)$ & $9.7 \%$ & to & $20.2 \%$ \\
\hline Black & 36 & $(7.0 \%)$ & $3.3 \%$ & to & $10.7 \%$ \\
\hline Yellow & 14 & $(2.7 \%)$ & $0.3 \%$ & to & $5.1 \%$ \\
\hline Other & 1 & $(0.2 \%)$ & $0.1 \%$ & to & $0.8 \%$ \\
\hline \multicolumn{6}{|l|}{ Induced Questions - N (\%) } \\
\hline Alopecia & 152 & $(29.5 \%)$ & $22.9 \%$ & to & $36.2 \%$ \\
\hline Melasma & 114 & $(22.1 \%)$ & $16.1 \%$ & to & $28.2 \%$ \\
\hline Onychomycosis & 110 & $(21.4 \%)$ & $15.4 \%$ & to & $27.3 \%$ \\
\hline Ingrown Toenail & 81 & $(15.7 \%)$ & $10.4 \%$ & to & $21.0 \%$ \\
\hline Acne Juvenile (only) & 206 & $(40.0 \%)$ & $32.9 \%$ & to & $47.1 \%$ \\
\hline Persistent & 120 & $(23.3 \%)$ & $17.1 \%$ & to & $29.5 \%$ \\
\hline Adult & 25 & $(4.9 \%)$ & $1.7 \%$ & to & $8.0 \%$ \\
\hline Consulted dermatologist - N (\%) & 397 & $(77.1 \%)$ & $71.0 \%$ & to & $83.2 \%$ \\
\hline Referred any dermatosis - N (\%) & 241 & $(46.8 \%)$ & $39.7 \%$ & to & $53.9 \%$ \\
\hline
\end{tabular}

TABLE 2: Main dermatoses spontaneously referred by interviewed employees $(n=515)$

\begin{tabular}{|c|c|c|c|c|c|}
\hline Diagnosis* & $\mathbf{N}$ & $\%$ & & CI $95^{\circ}$ & \\
\hline Mycoses & 87 & $16.9 \%$ & $11.4 \%$ & to & $22.4 \%$ \\
\hline Allergies & 59 & $11.5 \%$ & $6.8 \%$ & to & $16.1 \%$ \\
\hline Nevus & 22 & $4.3 \%$ & $1.3 \%$ & to & $7.2 \%$ \\
\hline Viral Wart & 16 & $3.1 \%$ & $0.6 \%$ & to & $5.6 \%$ \\
\hline Dark Spots & 13 & $2.5 \%$ & $0.2 \%$ & to & $4.8 \%$ \\
\hline Skin Cancer & 12 & $2.3 \%$ & $0.1 \%$ & to & $4.5 \%$ \\
\hline Acne & 11 & $2.1 \%$ & $0.1 \%$ & to & $4.2 \%$ \\
\hline Seborrheic Dermatitis & 7 & $1.4 \%$ & $0.1 \%$ & to & $3.0 \%$ \\
\hline Psoriasis & 6 & $1.2 \%$ & $0.1 \%$ & to & $2.7 \%$ \\
\hline Rosacea & 6 & $1.2 \%$ & $0.1 \%$ & to & $2.7 \%$ \\
\hline Epidermal Cyst & 6 & $1.2 \%$ & $0.1 \%$ & to & $2.7 \%$ \\
\hline Actinic keratosis & 6 & $1.2 \%$ & $0.1 \%$ & to & $2.7 \%$ \\
\hline Herpes simplex & 5 & $1.0 \%$ & $0.1 \%$ & to & $2.4 \%$ \\
\hline Seborrheic keratosis & 5 & $1.0 \%$ & $0.1 \%$ & to & $2.4 \%$ \\
\hline Herpes zoster & 5 & $1.0 \%$ & $0.1 \%$ & to & $2.4 \%$ \\
\hline Acrochordon & 4 & $0.8 \%$ & $0.1 \%$ & to & $2.1 \%$ \\
\hline Leukodermas & 3 & $0.6 \%$ & $0.1 \%$ & to & $1.7 \%$ \\
\hline Erysipelas & 3 & $0.6 \%$ & $0.1 \%$ & to & $1.7 \%$ \\
\hline Scabies & 3 & $0.6 \%$ & $0.1 \%$ & to & $1.7 \%$ \\
\hline Other & 55 & $10.7 \%$ & $4.8 \%$ & to & $13.1 \%$ \\
\hline
\end{tabular}

* The diagnoses referred were grouped by the authors. 
$\mathrm{p}=0.01)$; however, no association with the phototype was shown ( $\mathrm{p}=0.07)$.

Regarding the actively investigated diseases, juvenile acne affected $63.3 \%$ of the subjects, being more common in men $(74.3 \% \times 55.2 \%$; OR=2.3; $<<0.01)$. Melasma was more frequent in women $(34 \% \times 6 \%$; $\mathrm{OR}=8.0 ; \mathrm{p}<0.01)$. Onychomycosis was associated with older ages $(\mathrm{OR}=1.05 ; \mathrm{p}<0.01)$, reaching a prevalence of $30.3 \%$ after 50 years of age. Alopecia and ingrown toenail was not associated with sex, age or phototype.

The main dermatoses spontaneously reported are in table 2. Dermatoses of a clinical nature (mycoses and allergies) were especially mentioned, $2.3 \%$ of the subjects referred skin cancer and $1.2 \%$, psoriasis. Dark spots were the main cosmetic complaint, affecting $2.5 \%$ of the interviewed.

In a British population study, from 1975, it was observed that up to $22.5 \%$ of the population was carrying, at least, one dermatosis that required specific treatment, and up to $55 \%$ of the interviewed reported having received some dermatological diagnosis, a similar value to the one found in the present study. 4

In Brazil, a research conducted in the city of Campinas (SP), with 1,491 patients of all ages, revealed that approximately one in every ten patients who seek medical care in basic health units (BHU) did so due to a dermatosis, and one in every four patients cared for on these BHUs reported a dermatological complaint or finding that required specialized orientation or medical procedure. ${ }^{5}$

Still in Brazil, dermatological lesions were identified in $72 \%$ of children and teenagers in an investigative census of dermatological lesions in school age people in Ribeirão Preto (SP), reinforcing the evidence for high frequency of dermatological disease. ${ }^{6}$

\section{REFERENCES}

1. Sociedade Brasileira de Dermatologia. Nosologic profile of dermatologic visits in Brazil. An Bras Dermatol. 2006;81:549-58.

2. Wolkenstein P, Grob JJ, Bastuji-Garin S, Ruszczynski S, Roujeau JC, Revuz J, et al. French people and skin diseases: results of a survey using a representative sample. Arch Dermatol. 2003;139:1614-9.

3. Miot HA. Tamanho da amostra em estudos clínicos e experimentais. J Vasc Bras 2011;10: 275-8.

4. Rea JN, Newhouse ML, Halil T. Skin disease in Lambeth. A community study of prevalence and use of medical care. Br J Prev Soc Med. 1976;30:107-14.

5. Santos Junior A, Andrade MGG, Zeferino AB, Alegre SM, Moraes AM, Velho PENF. Prevalência de dermatoses na rede básica de saúde de Campinas, São Paulo - Brasil. An Bras Dermatol. 2007;82:419-24.

6. Bechelli LM, Haddad N, Pagnano PMG, Uthida Tanaka AM, Zanin LC, Rocha dos Santos MR0, et al. Censo epidemiológico de lesões e afecções cutâneas em escolares de Ribeirão Preto, SP, Brasil. Arch Argent Dermatol. 1990;40:45-59.

7. Lupi 0, Nunes S, Gomes Neto A, Pericles C. Doenças dermatológicas no Brasil: perfil atitudinal e epidemiológico. An Bras Dermatol. 2010; 85: S1-S20.

8. Penha MA, Santos PM, Miot HA. Dimensioning the fear of dermatologic diseases. An Bras Dermatol. 2012;87:796-9.
Similarly to our results, in a Brazilian population-based study with 1,500 adults, dermatological appointments were referred by $56 \%$ of the subjects, with pigmentation disorders, allergies, mycoses and acne as the most referred causes. ${ }^{7}$

The reasons for seeking the dermatologist vary with age, gender, social status, phototypes and geographic characteristics; however, many studies confirm high frequency of cutaneous diseases in the population, larger demand for health care by females and higher cumulative probability of requiring specialized care with age. ${ }^{1,5,7,8}$ In this sample, the highlights were high incidences of onychomycoses in people older than 50, facial melasma in women and dermatoses of a clinical nature as the most referred.

SUS considers adequate the proportion of one dermatologist for every 40,000 inhabitants, under the assumption that up to $80 \%$ of cases are resolved in the primary health system. Nevertheless, the low resolution of the $\mathrm{BHU}$ and the estimated $24.0 \%$ to $36.5 \%$ medical care services that refer a dermatological complaint should trigger discussions about health policies, health professionals training, primary prevention, medical school curriculum, health care system dimensioning and residency vacancies for the specialty. $5,9,10$

Our study presents the limitation of being based on patient reports instead of confirmed diagnoses. Anyway, in spite of the campus employees' group being very heterogeneous (teachers, researchers, technical, maintenance and cleaning personnel), it has easy access to specialized care which, consequently, maximizes the chance of their being correctly diagnosed, and allows a satisfactory estimation of the dimension of dermatological diseases in this population. $\square$

9. Oliveira TF, Monteguti C, Velho PENF. Prevalence of skin diseases at a healthcare clinic in a small Brazilian town. An Bras Dermatol. 2010;85:947-9.

10. Saude.mg.gov.ber [Internet]. Ministério da Saúde. Portaria $n^{0} 1101$, de 12 de junho de 2002. [acesso 11 abr 2013]. Disponível em: http://www.saude.mg.gov.br/images/documentos/PORTARIA_1101.pdf

\author{
MAILING ADDRESS: \\ Hélio Amante Miot \\ Departamento de Dermatologia e Radioterapia da \\ Faculdade de Medicina de Botucatu da Universidade \\ Estadual Paulista (UNESP), SN \\ 18618-000 - Botucatu, SP \\ Brazil \\ E-mail: heliomiot@fmb.unesp.br
}

How to cite this article: Ishiy PS, Ramos e Silva L, Penha MA, Handel AC, Miot HA. Skin diseases reported by workers from UNESP campus at Rubião Jr, Botucatu-SP (Brazil). An Bras Dermatol. 2014;89(3):529-31. 